\title{
Developmental Implications of Children Bedroom in the Interior Environment and Implementations of Adults Preferences
}

\author{
Bir İ̧̧ Mekan Çevresi Olarak Çocuk Odasının Çocuk Gelişimine \\ Etkileri ve Yetişkin Uygulamaları
}

Meryem YALÇIN, ${ }^{1}$ Kemal YILDIRIM, ${ }^{2}$ Ayşe Müge BOZDAYI ${ }^{1}$

\section{ABSTRACT}

Many sociologists, psychologists and environmental designers have suggested that physical environment is stimulating the senses of children where they can explore and experiment not only positively effects their learning ability and skills but also influences their behavior. However practitioners of children space design adapt their spatial perspectives to meet the clients' needs and find new ways to work imaginatively within budget constraints. For this reason the focus of this study is to discuss the expectations, preferences and necessities of children's bedrooms by adults as an example of their contemporary implementation and implications within the interior environment. The method used is examination of various publications, results of children study researches, surveys, observations in order to determine their needs, preferences, concerns and expectations. In the study 160 completed questionnaires were used under the following headings; The status of children with the possession of a room of their own, dimensions of the bedrooms, floor covering, wall papers or covering and wall colors, children desire to spend time in the room and the time spent, furniture, matters taken into account in preference of furniture, general and material preferences, while these present paradigms in the approach to children's bedrooms at the present day, the physical qualities that need to be included within the framework of this context is the matter of discussion and argument.

Keywords: Children bedrooms; adult preferences; interior environment; furniture.

\section{Öz}

Çocuğun mekân ile etkileşimi, mekânın çocuğa sunduğu imkânlara bağlıdır. Çocuğun keşfedebileceği, sınayabileceği, duyularını uyaran mekânların çocukların öğrenme kapasiteleri ve yetenekleri üzerinde olduğu kadar davranışları üzerinde olumlu etkileri olduğu birçok sosyolog, psikolog ve çevre tasarımcısı tarafindan ortaya konmuştur. Ancak profesyoneller çocuk mekan tasarımlarında mekansal bakış açılarını müşteri gereksinimlerine ve bütçelerine göre yönlendirmektedirler. Bu yüzden çalışmanın odak noktası yetişkinlerin çocuk odalarındaki beklentileri, terchleri ve gereksinimleri günümüzdeki etkileri ve iç mekandaki etkileridir.Çalışmanın yöntemi çeşitli kaynaklar, çocuk araştırma verileri, anketler, gözlem sonucunda elde edilen verilere dayanarak çocukların mekansal ihtiyaç, tercih ve beklentileri tespit edilmesinden oluşmuştur. Bu kapsamda 160 katlımcıya uygulanan anketlerin ana başIıkları şöyledir: Çocukların Bağımsız Oda Durumu, Odaların Boyutları, Zemin Kaplama, Duvar Kaplaması ve Duvar Rengi, Odalarda Kalma Isteği ve Geçirilen Süre, Mobilyalar, Genel ve Malzeme Tercihlerine ve Mobilya seçiminde dikkat edilen hususlar günümüz koşullarında çocuk odasına yaklaşım konusunda örneklem oluştururken, bu örneklem çerçevesinde günümüz koşulları içersinde olması gereken fiziksel nitelikleri tartışmaktadır.

Anahtar sözcükler: Çocuk ddaları; yetişkin tercihleri; iç mekan; mobilya.

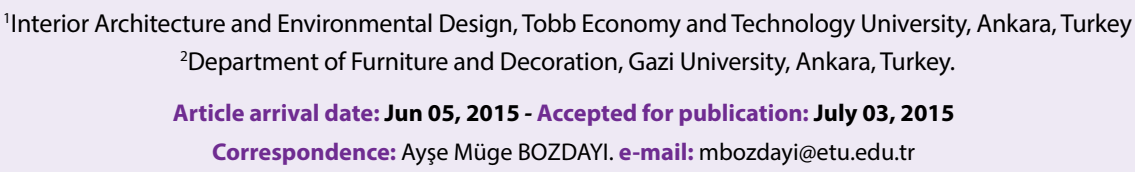




\section{Introduction}

As presented in the latest studies in Experimental Psychology, it has been observed that particularly during early childhood, every stimuli of the physical and social environment becomes a discovery and learning experience which forms the fundamentals of intellectual, physical, social, emotional and perceptual development (Day\&Midbjer, 2007; Gür\&Zorlu, 2002; Dudek, 2000 and 2001; Weinstein\&David, 1987; Moore, 2002). For this reason it is essential to create ideal contexts in physical environments which stimulate the learning process and development of children (Feldman, 2007; Gür\&Zorlu, 2004; Dudek, 2001) While providing important aspects such as comfort and safety; creating a controlled and rigorously evaluated environment, that also focuses on the health and safety of children over and above their social and cognitive development is necessary. (Moore, 2002; Bozdayı, 1988; Weinstein\&David, 1987). In this context creating spaces for children and considering every aspect presents a special challenge for designers, as children's spaces plays a critical role in helping to pacify or stimulate children as appropriate to their needs. Especially in the period of early childhood when a large portion of a child's life is spent in the interior environment, it is clear that the quality of this living in the housing interior environment as part is crucial in children's development.

However, children are not usually involved in planning the buildings they have to live in. They are, in fact, invisible clients. They spent their lives in a built environment, yet they have no input into the design, aesthetic, function or organization of it (Dudek, 2005; Moore, 2002; Korpela et al., 2002). It is therefore up to the adults in charge to develop suitable design criteria. In this context one of the most important issues in child-parent relationship is the awareness of the important contributions of the physical environment to the development of the children (Rudge\&Driskoll, 2005; Burdurlu et al., 2004; Moore, 2002; Dogramaci, 1994). Because, the affinity of a children's rooms is reflected in the interior environment within the scope of parents' knowledge. The attitude, knowledge and expectations of the parents affect the designing process of any spatial unit designed for children. Parent's description of the ideal context environment can provide designers with significant insight to design priorities of the physical environment of early childhood spaces (Yalcin, 2011; Burdurlu et al., 2004; Dudek, 2001).

Correspondingly, "qualified" in terms of physical environmental qualities, is a concept considerably relative and difficult overlapping phenomenon in chil- dren spaces (Read, 2007; Dudek, 2001; Gür\&Zorlu, 2002; Bozdayı, 1988). Since the space not only needs to represent the developmental stage but also it has to be taken as a whole with many factors like a child's psychology, development, identity, abilities and culture. This such space's proposition with regard to universally accepted values and its sub-components of comprehension will be the scope of design set-up (Stankovic\&Stojic, 2007; Christensen\&James, 2000; Tolfree\&Woodhead, 1999; Miller, 1986).

Children spend more time in their homes than anywhere else (Gifford \& Lacombe, 2006). And it is stated that one third of children's life is spent in the bedroom (Buyukpamukcu, 2004). He also emphasizes the fact that the bedroom is no longer a room strictly reserved for sleeping. The room becomes a place used for various activities such as: reading, playing games, conversation, working, watching television or video, listening to music, etc. The whole world of new customs and leisure pursuits has taken over in the bedroom which is reflected in the furniture design (Buyukpamukcu, 2004; Egill, 2002; Garbarini, 1999; Kanbay, 1993).

On the other hand, a child's bedroom is a place where they lay the foundation for their future. It is a room which consists of their broadest requirements and a place that a being's all contemporary habitats initiate in full preparation for tomorrow. The presence of these requirements in children's immediate environment shapes a child's identity (Demirarslan\&Aytöre, 2004; Büyükpamukçu, 2004; Frost et al., 2001).

Moreover, a child's physical environment that is created by adults with adult understanding is "the world of small objects within a world of bigger objects" (Veechi, 1998; Weinstein\&David, 1987). Although this maybe the case, children have broad imagination to use every object as raw material to recreate their own world despite the environment which have been prepared in full or in part by adults. The prepared space should ideally be (1) a place that a child can dominate rather than be dominated by; (2) a place that encourages movements of children, allowing the immediate formation of any type that suit educational needs; and (3) a place that provides comfort, beauty and stimulation (Stankovic et al., 2006; Şener, 2001). This place should create a fundamental influence of sensory stimuli on children's development; the design set-up of the space should encourage them to be creative, sensitive, imaginative, and original. The spatial perception of children is different and their point of view is considerably restricted compared to that of adults (Yavuzer, 2008; Dudek, 2000). 


\section{Children Spaces}

Human beings are in continual interaction with their physical and social environment. Throughout this interaction process the individual develops behavior that is compatible with the environmental requirements (Stankovic\&Stojic,2007; Day\&Midbjer, 2007; Gür\&Zorlu, 2002; Bozdayı, 1988). Correlation between the housing environment and child development is a multidisciplinary subject that has important policy implications. This correlation transcends the sociological discussion (Li, 2011). Children are not passive beings that are exposed unilaterally to the stimuli from the environment but they are individuals that have an active affect in their development. Their environments must take this interaction in to account in providing designs that consist of a rich set of possibilities (Şener, 2001, Frost et al., 2001). Therefore these spaces must provide children with the opportunity to explore through people, events and objects; by enabling them to acquire experiences by experimenting and imitating (Read, 2007; Dudek, 2001; Tolfree\&Woodhead, 1999). Also the fact that children are actually in both internal and exterior spaces in terms of different environments increases their sensory skills (Yavuzer, 2008).

Maslow $(1937 ; 1945)$ has studied the psycho-social and cultural requirements that determine children's behavior. According to Maslow, children's requirements are similar to adults but in different terms. These requirements consists starting from the most fundamental biological one is; security, need to belong-to connect, respectability, proving one's self and intellectual, emotional and aesthetic satisfaction. Children feel the need to establish relationships with the physical environment as much as social environment. These relationships consists of objects, spaces and locations that may or may not meet children's spatial experience requirements which are biological, physical, social and cultural. As a result, the ability of the space to arouse the children's feeling of belonging and of familiarity will facilitate their connection with their environment. In order for them to have a healthy development there is a need for spatial confidentiality and availability of freedom in the space. Possession of an area that is exclusively theirs will be of assistance in the development of the child's personality and will reinforce their self-confidence (Gür et al., 2002).

Another essential requirement of children spaces is; it has to "communicate important messages to them about who they are and what they may aspire to be" (Veechi, 1998; Miller, 1986). A warm, nurturing, stim- ulating environment communicates to children that they are valued and their way of learning is agreed and respected. A dull, disorganized, or impoverished environment on the other hand suggests to children that they are not valued or respected. Such messages have a strong impact on how children perceive themselves as learners and explorers. This, of course, also affects self-esteem, feelings of competence and sense of establishment. Being acquainted to a place "where you are and where you come from" is intertwined with who you are. In other words, Landscape shapes mindscape (Stankovic\&Stojic, 2007; Moore, 2002).

Within this scope, factors such as the children's physical requirements, development of their psychosocial skills and imagination, feelings of responsibility, biological and cultural needs, relations with friends, variety, grouping and order of the fields of activity are all factors that must be taken into account when designing children's spaces and these factors must be incorporated as a part of a whole system (Read, 2007; Yildirim et al., 2006; Gür\&Zorlu, 2002). In addition, the more stimulation the children are exposed to the more their development in a variety of different areas will be supported. The scale concept in the physical space (large or small spaces, private or semi-private spaces, multipurpose furniture); floor height (raised or lowered platforms, bumps and depressions), height of ceilings and the boundary elements (walls, half sized dividers, low shelves) can be discussed as some of the factors that support children development and those that are stimulating. Sensory variety is reinforced when individual and common areas are created to inter-relate different activities. The assortments created in each space will increase the diversity of experiences and playing opportunities which will contribute more effectively to the development of the children (Dudek, 2001; Korpela et al., 2002; Şener, 2001).

Consequently, a comprehensive understanding of the relationship between their space and the children are in need. The physical-social aspects can only be achieved through resolution of even the smallest details that involve the spaces creation. Each detail contributes to the children's physical, psycho-social and cognitive perception development (Stankovic\&Stoic, 2007). For the reasons mentioned above, housing interior bedroom designed for children where they will spend a major part of their time need to be developed by spatial requirements for the child including; biological, physiological and psycho-social attributes that enable them to prove themselves, stimulate aesthetic feelings and impart a feeling of independence. 


\section{Children Bedrooms}

The family is primarily responsible for the education process which is a requirement for the nurture, development and requirements of the children. To enable physical and mental development, appropriate social and bodily stimulation must be provided to them during their childhood where permanent behavior patterns are acquired. This development will be strongly supported by means of a suitable designed environment. The rooms where a child will spend a majority of time and the furniture in that room have a stimulating effect on the child's physical development. Children can carry out play and educational activities jointly in this space. Therefore, the children's bedroom needs to be designed specifically for children in the housing environment (Egill, 2002; Doğramacı, 1994). Children's bedrooms that are out of the ordinary, colorful and that have movement present the first phase of raising a child that possesses freedom of thought and the required skills. From a developmental perspective, supporting the children's imaginations and giving them a place they like to live in is essential for the psychology and the development of a healthy individual (Kanbay, 1993).

The materials favored by parents and children furniture manufacturers contains many qualities such as functionality, easy to manufacture, hygienic, easily cleanable, durability and able to give confidence to children from a psychological perspective (Buyukpamukcu, 2004). Also, in addition to these, children's bedroom furniture and fittings need to contain components that support the development of children and are adaptable and compatible with the activities that are carried out by the child. In order for these spaces to stimulate the imagination of the child they should be; comfortable and allow for free play, stimulating to develop their creativity, and providing for the education of the child. These attributes for the furniture and fittings are determinants for the multi-dimensional development of children (Yalcin, 2011, Yildirim\&Baskaya, 2006; Stankovic et al., 2006).

To sum up, the determinants can be summarized as softness, security, safety, privacy, order, freedom, movement, flexibility/multipurpose, adult scale dimensions and ergonomics and are taken into account in part by adults (Demirarslan, 2004; Büyükpamukçu, 2004).

On the other hand, when children are growing up their needs and expectations change according to their physical and psychological development. Children will feel joy towards a variety of activities which are characteristic of each developmental period (Gür\&Zorlu, 2002; Tolfree\&Woodhead, 1999). Therefore, it is important to consider the traits of children in different age groups when making suggestions about the characteristics and attributes of their environments. This approach will open the way for the children to take part in the in the creation of their spaces and build their participation into the decision making process for the design of their spaces. The fittings also must be adapted to a child instead of an approach where adults only are involved in the designing process. This way, the fittings and the accessories in the room where children spend a majority of their time will assume a stimulating role in the housing environment of children (Burdurlu et al., 2004; Moore, 2002; Garbarini, 1999). According to this, a space primarily designed with children in mind, where they will find a lot of themselves in, which belongs exclusively to them and which was shaped based on their decisions will play an important role in their mental development. This process in turn will assist in; increasing the chance that they will be successful individuals, development of their personality and self-confidence and also reduction of possible risks of accidents which collectively will contribute positively to raising their quality of life. Consecutively, the scope of this study has been structured within above mentioned framework.

\section{Theoretical Background and Hypotheses}

There is a growing awareness internationally for the importance of early childhood development and its impact on the individuality of the child. Early child development has wider impact on the social and economic capacity of communities and nations (Day\&Midbjer, 2007; Gür\&Zorlu, 2002; Tolfree\&Woodhead, 1999). As mentioned before, the physical environment is seen as a critical partner in children's cognitive, social and physical development. For this reason; design requirements for children bedroom furniture and interior environment are examined through analyzing contemporary adult preferences and expectation in this study. Children's bedrooms are the spaces in which they are the main active users of this space. Therefore, the decisions about the design of these environments should be made by the consideration of young children as the primary users while still in connection with the existence of the adults (Rudge\&Driskoll, 2005; Kanbay, 1993). The aim of this study is to point out the main design principles which are consistent with the need and expectations of the young children.

When designing children's bedrooms it is necessary 
to unite play and learning activities, and to present it to the child with multiple alternatives. In the light of everything that has been outlined up to now, this can be summarized as an environment that meets and supports the child's fundamental requirements. Some of the fundamental requirements are; feeding, love and affection, security, movement, adult support, together with other children, play, self-recognition and proving oneself, freedom and creativity, and development of aesthetic sense to support creativity. In this study, people who were shopping in the Ankamall Shopping Centre located in the Yenimahalle district of Ankara, Turkey were used. Respondents were randomly selected from the families with children and 160 completed questionnaires were applied under the subheadings of; The status of independent children's rooms, the dimensions of the rooms, floor covering in the room, wall papers or coverings and wall colors, the desire to spend time in the room and the time spent, furniture inside the room, matters taken into account in selection of this furniture, general and material preferences in order to find the following issues out;

\section{Problem Sentence}

Although parents are now much more aware of the developmental effects of interior spatial properties and furniture selections on children bedroom, they still choose to provide functionality only and prefer conventional and ordinary bedroom designs for them.

\section{Sub-problems}

1. Children are subject to the decisions of the adults in terms of shaping of their worlds. As a result, their bedroom's interiors are organized by adults and are presumed by them that they will find this space amenable.

2. Children bedrooms covers very ordinary interior spatial and furniture design properties of respondents.

3. The physical environments that develop the children's personalities, preferences and their knowledge of skills must consist of original designs.

4. A child's bedroom must have spatial design features such as; identity, self-recognition, challenge, support for independence and creativity.

\section{Hypotheses}

H1: Children's bedroom interior and furniture properties will house very many similar spatial qualities.

H2: Functional issues will present more respect than other children developmental requirements.

H3: Children's developmental requirements are still a missing matter of their bedroom interior and furniture design.

H4: Children bedroom's interior and furniture design are still under the supervision of the adults.

H5: Design requirements for children's bedroom furniture and interior environment are effected from the contemporary children furniture market.

The goal of this study is to deliver a report of design aspects in a children's bedroom environment and furniture that may positively contribute to the development of children. We investigated whether these aspects can be of use in forming the children's bedrooms design criteria and also if it can form the characteristics of contemporary expectations and requirements of users and markets for children bedroom furniture. The consumer evaluations depended upon the variables in the furniture store atmospheric features and many factors affected the evaluation of children' rooms and furniture in the interior environment.

\section{Methodology}

\section{Frame of Respondents}

This research was carried out with families with children who were shopping in the Ankamall Shopping Centre located in the Yenimahalle district of Ankara, Turkey. Respondents were randomly selected from among the families with children using the shopping centre and 160 completed questionnaires.

\section{Questionnaire Design}

Based on the research hypotheses presented above, a two dimension survey of dependent variables were developed and measured via a children room questionnaire consisting of multiple-choice questions validated and found to be reliable in previous research (Işık, 1992; Yildirim, 1995; Yildirim\&Hacibaloglu, 2000; Yildirim et al., 2005; Yildirim\&Baskaya, 2006; Yildirim\&Hidayetoglu, 2008). The questionnaire was pre-tested with 17 families with children and was subsequently modified and refined. The survey assessed two dimensions: I. the findings concerning children roomspaces, II. the findings regarding the furniture in the children' rooms.

The questionnaires were self-administered, with interviewers present to address any difficulties or que- 
ries. The survey was applied at various times of day during the week or on the weekends. On average, respondent completed the survey in approximately 20 minutes. The data were obtained over a 2-month period at the beginning of 2013 .

\section{Data Collection}

The dependent variablesconsisted of respondents evaluations of children' bedrooms. Many factors affect the evaluation of children' rooms and furniture. Of these, this study assessed age and gender as independent variables, enumerated and defined as follows:

$$
\begin{aligned}
& \text { X1: Age (0-4, 5-7, 8-10, 11-13) } \\
& \text { X2: Gender (Male, Female) }
\end{aligned}
$$

The reliability coefficients of the data thus obtained were defined based on their percentage values. Then, to examine the effect of age and gender on evaluations of children rooms in the housing interior environment, the chi-square $\left(x^{2}\right)$ was applied.

\section{Results}

The findings relating to the architectural features and fittings components obtained in the study are given below in order.

\section{Findings on Children's Room Space}

The status of the children from families that partici- pated in the study, in respect of possession of a room of their own is given below in Table 1 .

According to Table 1 of the children from families that participated in the study $51.9 \%$ were girls, $48.1 \%$ boys, $20 \%$ were in the age group $0-4,25.6 \%$ were in the age group $5-7,30.6 \%$ were in the age group $8-10$, and $23.8 \%$ were in the age group $11-13$. Also it can be seen that $87.5 \%$ of children in the study have a room of their own. In the Chi-Square test carried out, it was determined that there was statistically significant difference (at the $p<0.05$ level) between age groups of children with rooms of their own, however there was no difference according to gender. According to the findings, children in the $0-4$ age group, had the least rooms of their own in comparison to other age groups. Next the dimensions of the rooms of children that possessed of a room of their own or shared with their brothers or sisters is given in Table 2. These results support in a way $\mathrm{H} 4$. Since the area of bedroom and privacy are very basic needs of children and do not have a direct bearing their age. But the participants determined it to be a correlation with the age.

According to Table 2 half of the children rooms dimensions were in the range $8-10 \mathrm{~m}^{2}$ and the other half had rooms of size 11-13 $\mathrm{m}^{2}$. In the chi square test carried out, it was determined that there was no statistically significant difference (at the $p<0.05$ level) be-

\begin{tabular}{|c|c|c|c|c|c|c|c|c|c|c|c|c|c|c|}
\hline \multirow{3}{*}{$\begin{array}{l}\text { Status of the children in } \\
\text { possession of a room } \\
\text { of their own }\end{array}$} & \multicolumn{8}{|c|}{ Age } & \multicolumn{4}{|c|}{ Gender } & \multicolumn{2}{|c|}{ Total } \\
\hline & \multicolumn{2}{|c|}{$0-4$} & \multicolumn{2}{|c|}{$5-7$} & \multicolumn{2}{|c|}{$8-10$} & \multicolumn{2}{|c|}{$11-13$} & \multicolumn{2}{|c|}{ Female } & \multicolumn{2}{|c|}{ Male } & \multirow[b]{2}{*}{$\mathbf{F}$} & \multirow[b]{2}{*}{$\%$} \\
\hline & $\mathbf{F}$ & $\%$ & $\mathbf{F}$ & $\%$ & $\mathbf{F}$ & $\%$ & $\mathbf{F}$ & $\%$ & $\mathbf{F}$ & $\%$ & $\mathbf{F}$ & $\%$ & & \\
\hline Number of children & 32 & 20 & 41 & 25.6 & 49 & 30.6 & 38 & 23.8 & 83 & 51.9 & 77 & 48.1 & 160 & 100 \\
\hline Status of a room of their own & 20 & 12.5 & 39 & 24.4 & 45 & 28.1 & 36 & 22.5 & 71 & 44.4 & 69 & 43.1 & 140 & 87.5 \\
\hline
\end{tabular}

Table 1. The status of the children in possession of a room of their own

Note: Age ( $X^{2}: 23.126$, df:3, Sig.0.000) and Gender ( $X^{2}: 0.604$, df:1, Sig.0.437)

$X^{2}$ : Chi Square; df: Degree of freedom; F: The number of subjects, \%: The percentage value.

\begin{tabular}{|c|c|c|c|c|c|c|c|c|c|c|c|c|c|c|}
\hline \multirow[t]{3}{*}{ Rooms dimensions } & \multicolumn{8}{|c|}{ Age } & \multicolumn{4}{|c|}{ Gender } & \multicolumn{2}{|c|}{ Total } \\
\hline & \multicolumn{2}{|c|}{$0-4$} & \multicolumn{2}{|c|}{$5-7$} & \multicolumn{2}{|c|}{$8-10$} & \multicolumn{2}{|c|}{$11-13$} & \multicolumn{2}{|c|}{ Female } & \multicolumn{2}{|c|}{ Male } & \multirow[b]{2}{*}{$\mathbf{F}$} & \multirow[b]{2}{*}{$\%$} \\
\hline & $\mathbf{F}$ & $\%$ & $\mathbf{F}$ & $\%$ & $\mathbf{F}$ & $\%$ & $\mathbf{F}$ & $\%$ & $\mathbf{F}$ & $\%$ & $\mathbf{F}$ & $\%$ & & \\
\hline $8-10 m^{2}$ & 13 & 8.1 & 25 & 15.6 & 22 & 13.8 & 20 & 12.5 & 42 & 26.2 & 38 & 23.8 & 80 & 50 \\
\hline $11-13 m^{2}$ & 19 & 11.9 & 16 & 10 & 27 & 16.9 & 18 & 11.3 & 41 & 25.6 & 39 & 24.4 & 80 & 50 \\
\hline
\end{tabular}

Table 2. The status of the children in possession of a room of their own

Note: Age ( $X^{2}: 3.716$, df:3, Sig.0.294) and Gender ( $X^{2}: 0.025$, df:1, Sig.0.874). 
tween children's rooms dimensions according to age or gender groups. In Table 3 below the floor coverings of children according to age or gender groups is given.

According to Table 3 it can be seen that over half of the children's rooms had carpets over laminated parquet and $31.3 \%$ had carpet over wood parquet. From the results it can been that wood or wood based floor covering was used in the children's rooms. Another result that emerged was wall to wall carpeting, or PVC based materials were not preferred. On the other hand no significant difference between age and gender has been found in the $p<0.05$ level Chi-Square test. Whereas Table 3 and 4 supports $\mathrm{H} 5$ these findings shows children's interior design elements are effected from the contemporary market, because almost no one has the other options been selected by respondents. In Table 4 below, the wall coverings used in the rooms according to age and gender of the children are given.

According to Table 4 over half of the children's rooms had water-based paint, \%21.9 had wallpaper, $\% 13.8$ had plastic paint and $10 \%$ had silicone-based paint. From these results it can be seen that waterbased paint was mainly preferred by the families On the other hand no significant difference between age and gender has been found in the $p<0.05$ level ChiSquare test. In parallel with this the colors used on children's rooms is given in Table 5 .

According to Table 5, it can be seen that in 31.9\% of the children's rooms white was used on the wall, $19.4 \%$ blue, $14.4 \%$ yellow and $13.8 \%$ had pink. No significant difference between ages have been found in the $p<0.05$ level Chi-Square test, However there is a significant difference between blue $\left(X^{2}: 19.680\right.$, df:1, Sig.0.000) and pink ( $X^{2}:$ 19.404, df:1, Sig.0.000) color statistically in the $p<0.05$ level. From these results it can deduced that in the girls rooms, pink was evidence while in the boys rooms blue was in abundance. As stated in $\mathrm{H} 1$ the properties in tables of 4 and 5 show again very similar and can become easily general In Table 6 below, desire of the children from participating families to stay in their rooms and durations in days spent are given according to gender and age group.

According to Table 6 it can be seen $73.1 \%$ of the children like to stay in their rooms and that $45.6 \%$ spend 3-4 hours a day, $33.1 \%$ spend $1-2$ hours and $13.1 \%$ spends 5-6 hours. As a result it can be seen that the 8-10 age group children like to stay in their rooms more

Table 3. The floor coverings of children's rooms

\begin{tabular}{|c|c|c|c|c|c|c|c|c|c|c|c|c|c|c|}
\hline \multirow[t]{3}{*}{ Floor coverings of the rooms } & \multicolumn{8}{|c|}{ Age } & \multicolumn{4}{|c|}{ Gender } & \multicolumn{2}{|c|}{ Total } \\
\hline & \multicolumn{2}{|c|}{$0-4$} & \multicolumn{2}{|c|}{$5-7$} & \multicolumn{2}{|c|}{ 8-10 } & \multicolumn{2}{|c|}{$11-13$} & \multicolumn{2}{|c|}{ Female } & \multicolumn{2}{|c|}{ Male } & \multirow[b]{2}{*}{$\mathbf{F}$} & \multirow[b]{2}{*}{$\%$} \\
\hline & $\mathbf{F}$ & $\%$ & $\mathbf{F}$ & $\%$ & $\mathbf{F}$ & $\%$ & $\mathbf{F}$ & $\%$ & $\mathbf{F}$ & $\%$ & $\mathbf{F}$ & $\%$ & & \\
\hline Wall to wall carpeting & 4 & 2.5 & 5 & 3.1 & 1 & 0.6 & 2 & 1.3 & 8 & 5 & 4 & 2.5 & 12 & 7.5 \\
\hline Carpet over wood parquet & 11 & 6.9 & 14 & 8.8 & 14 & 8.8 & 11 & 6.9 & 25 & 15.6 & 25 & 15.6 & 50 & 31.3 \\
\hline Carpet over PVC, Vinyl etc. & 2 & 1.3 & 1 & 0.6 & - & - & 3 & 1.9 & 1 & 0.6 & 5 & 3.1 & 6 & 3.8 \\
\hline Carpet over laminated parquet & 14 & 8.8 & 19 & 11.9 & 34 & 21.3 & 21 & 13.1 & 48 & 30 & 40 & 25 & 88 & 55 \\
\hline Other & - & - & 2 & 1.3 & - & - & 2 & 1.3 & 1 & 0.6 & 3 & 1.9 & 4 & 2.5 \\
\hline
\end{tabular}

Table 4. The wall coverings used in the children's rooms

\begin{tabular}{|c|c|c|c|c|c|c|c|c|c|c|c|c|c|c|}
\hline \multirow[t]{3}{*}{ Wall coverings of the rooms } & \multicolumn{8}{|c|}{ Age } & \multicolumn{4}{|c|}{ Gender } & \multicolumn{2}{|c|}{ Total } \\
\hline & \multicolumn{2}{|c|}{$0-4$} & \multicolumn{2}{|c|}{$5-7$} & \multicolumn{2}{|c|}{ 8-10 } & \multicolumn{2}{|c|}{ 11-13 } & \multicolumn{2}{|c|}{ Female } & \multicolumn{2}{|c|}{ Male } & \multirow[b]{2}{*}{$\mathbf{F}$} & \multirow[b]{2}{*}{$\%$} \\
\hline & $\mathbf{F}$ & $\%$ & $\mathbf{F}$ & $\%$ & $\mathbf{F}$ & $\%$ & $\mathbf{F}$ & $\%$ & $\mathbf{F}$ & $\%$ & $\mathbf{F}$ & $\%$ & & \\
\hline Wallpaper & 11 & 6.9 & 8 & 5 & 7 & 4.4 & 9 & 5.6 & 19 & 11.9 & 16 & 10 & 35 & 21.9 \\
\hline Plastic paint & - & - & 6 & 3.8 & 9 & 5.6 & 7 & 4.4 & 10 & 6.3 & 12 & 7.5 & 22 & 13.8 \\
\hline Water-based paint & 12 & 7.5 & 21 & 13.1 & 30 & 18.8 & 21 & 13.1 & 46 & 28.8 & 38 & 23.8 & 84 & 52.5 \\
\hline Silicone-based paint & 7 & 4.4 & 4 & 2.5 & 4 & 2.5 & 1 & 0.6 & 8 & 5 & 8 & 5 & 16 & 10 \\
\hline Others & 1 & 0.6 & 1 & 0.6 & 1 & 0.6 & - & - & 1 & 0.6 & 2 & 1.3 & 3 & 1.9 \\
\hline
\end{tabular}


Table 5. The colors used on children's rooms walls

\begin{tabular}{|c|c|c|c|c|c|c|c|c|c|c|c|c|c|c|}
\hline \multirow[t]{3}{*}{ Wall coverings of the rooms } & \multicolumn{8}{|c|}{ Age } & \multicolumn{4}{|c|}{ Gender } & \multicolumn{2}{|c|}{ Total } \\
\hline & \multicolumn{2}{|c|}{$0-4$} & \multicolumn{2}{|c|}{$5-7$} & \multicolumn{2}{|c|}{$8-10$} & \multicolumn{2}{|c|}{$11-13$} & \multicolumn{2}{|c|}{ Female } & \multicolumn{2}{|c|}{ Male } & \multirow[b]{2}{*}{$\mathbf{F}$} & \multirow[b]{2}{*}{$\%$} \\
\hline & $\mathbf{F}$ & $\%$ & $\mathbf{F}$ & $\%$ & $\mathbf{F}$ & $\%$ & $\mathbf{F}$ & $\%$ & $\mathbf{F}$ & $\%$ & $\mathbf{F}$ & $\%$ & & \\
\hline Blue & 11 & 6.9 & 6 & 3.8 & 8 & 5 & 6 & 3.8 & 5 & 3.1 & 26 & 16.3 & 31 & 19.4 \\
\hline Pink & 3 & 1.9 & 5 & 3.1 & 9 & 5.6 & 5 & 3.1 & 21 & 13.1 & 1 & 0.6 & 22 & 13.8 \\
\hline Yellow & 5 & 3.1 & 5 & 3.1 & 8 & 5 & 5 & 3.1 & 11 & 6.9 & 12 & 7.5 & 23 & 14.4 \\
\hline Green & 3 & 1.9 & 2 & 1.3 & 3 & 1.9 & 4 & 2.5 & 3 & 1.9 & 9 & 5.6 & 12 & 7.5 \\
\hline Orange & 2 & 1.3 & 1 & 0.6 & 3 & 1.9 & - & - & 4 & 2.5 & 2 & 1.3 & 6 & 3.8 \\
\hline Red & 1 & 0.6 & 1 & 0.6 & 1 & 0.6 & 2 & 1.3 & 1 & 0.6 & 4 & 2.5 & 5 & 3.1 \\
\hline White & 11 & 6.9 & 13 & 8.1 & 16 & 10 & 11 & 6.9 & 29 & 18.1 & 22 & 13.8 & 51 & 31.9 \\
\hline Grey & - & - & 1 & 0.6 & 2 & 1.3 & 3 & 1.9 & 2 & 1.3 & 4 & 2.5 & 6 & 3.8 \\
\hline Others & 7 & 4.4 & 13 & 8.1 & 13 & 8.1 & 12 & 7.5 & 30 & 18.8 & 15 & 9.4 & 45 & 28.1 \\
\hline
\end{tabular}

Table 6. The desire of the children to stay in their rooms and durations in days spent

\begin{tabular}{|c|c|c|c|c|c|c|c|c|c|c|c|c|c|c|}
\hline \multirow{3}{*}{$\begin{array}{l}\text { Desire to stay in the room } \\
\text { and the time spent in days }\end{array}$} & \multicolumn{8}{|c|}{ Age } & \multicolumn{4}{|c|}{ Gender } & \multicolumn{2}{|c|}{ Total } \\
\hline & \multicolumn{2}{|c|}{$0-4$} & \multicolumn{2}{|c|}{$5-7$} & \multicolumn{2}{|c|}{$8-10$} & \multicolumn{2}{|c|}{$11-13$} & \multicolumn{2}{|c|}{ Female } & \multicolumn{2}{|c|}{ Male } & \multirow[b]{2}{*}{$\mathbf{F}$} & \multirow[b]{2}{*}{$\%$} \\
\hline & $\mathbf{F}$ & $\%$ & $\mathbf{F}$ & $\%$ & $\mathbf{F}$ & $\%$ & $\mathbf{F}$ & $\%$ & $\mathbf{F}$ & $\%$ & $\mathbf{F}$ & $\%$ & & \\
\hline Likes to stay in the room & 25 & 15.6 & 28 & 17.5 & 35 & 21.9 & 29 & 18.1 & 65 & 40.6 & 52 & 32.5 & 117 & 73.1 \\
\hline Spends $1-2$ hours a day & 12 & 7.5 & 18 & 11.3 & 13 & 8.1 & 10 & 6.3 & 21 & 13.1 & 32 & 20 & 53 & 33.1 \\
\hline Spends 3-4 hours a day & 11 & 6.9 & 17 & 10.6 & 27 & 16.9 & 18 & 11.3 & 44 & 27.5 & 29 & 18.1 & 73 & 45.6 \\
\hline Spends 5-6 hours a day & 5 & 3.1 & 5 & 3.1 & 3 & 1.9 & 8 & 5 & 12 & 7.5 & 3 & 5.6 & 21 & 13.1 \\
\hline Spends 7-8 hours a day & 3 & 1.9 & - & - & 6 & 3.8 & 2 & 1.3 & 5 & 3.1 & 6 & 3.8 & 11 & 6.9 \\
\hline
\end{tabular}

Table 7. Status of potted plants in children's rooms

\begin{tabular}{|c|c|c|c|c|c|c|c|c|c|c|c|c|c|c|}
\hline \multirow{3}{*}{$\begin{array}{l}\text { Desire to stay in the room } \\
\text { and the time spent in days }\end{array}$} & \multicolumn{8}{|c|}{ Age } & \multicolumn{4}{|c|}{ Gender } & \multicolumn{2}{|c|}{ Total } \\
\hline & \multicolumn{2}{|c|}{$0-4$} & \multicolumn{2}{|c|}{$5-7$} & \multicolumn{2}{|c|}{$8-10$} & \multicolumn{2}{|c|}{$11-13$} & \multicolumn{2}{|c|}{ Female } & \multicolumn{2}{|c|}{ Male } & \multirow[b]{2}{*}{$\mathbf{F}$} & \multirow[b]{2}{*}{$\%$} \\
\hline & $\mathbf{F}$ & $\%$ & $\mathbf{F}$ & $\%$ & $\mathbf{F}$ & $\%$ & $\mathbf{F}$ & $\%$ & $\mathbf{F}$ & $\%$ & $\mathbf{F}$ & $\%$ & & \\
\hline Potted plants are present & 2 & 1.3 & 4 & 2.5 & 15 & 9.4 & 8 & 5 & 22 & 13.8 & 7 & 4.4 & 29 & 18.1 \\
\hline No potted plants & 30 & 18.8 & 37 & 23.1 & 34 & 21.3 & 30 & 18.8 & 61 & 38.1 & 70 & 43.8 & 131 & 81.9 \\
\hline
\end{tabular}

Note: Age ( $X^{2}: 10.344$, df:3, Sig.0.016) and Gender ( $X^{2}: 8.163$, df:1, Sig.0.004)

in comparison to other age groups, and another result that emerges is that girls like theirs rooms more than the boys and spend longer times. On the other hand no significant difference between age have been found in the $p<0.05$ level Chi-Square test on the delectation of spending time in the room. However, there is a statistical difference between gender, spending 1-2 ( $X^{2}$ : 4.766, df:1, Sig.0.022) and 3-4 hours ( $X^{2}: 3.794$, df:1, Sig.0.037) in the room. Below the presence of potted plants of the children from families that participated in the study children from families that participated in the study according to age and gender is given in Table 7.

According to Table 7 of the 160 families children that participated in the study $18.1 \%$ had potted plants in their rooms. On the other hand no significant difference between age and gender has been found in the $p<0.05$ level Chi-Square test on the presence of potted plants. As a result it can be seen that more girls have 
Table 8. Furniture found in children's rooms

\begin{tabular}{|c|c|c|c|c|c|}
\hline Furniture & $\mathbf{F}$ & $\%$ & Furniture & $\mathbf{F}$ & $\%$ \\
\hline Bed with bed base with storage & 97 & 60.6 & Make-up table & 11 & 6.9 \\
\hline Bed without bed base with storage/bedstead & 63 & 39.4 & Study table & 111 & 69.4 \\
\hline Bedside table & 51 & 31.9 & Book shelves & 77 & 48.1 \\
\hline Chest of drawers & 87 & 54.4 & TV stand & 7 & 4.4 \\
\hline Wardrobe & 142 & 88.8 & others & 26 & 16.3 \\
\hline
\end{tabular}

Table 9. The characteristics taken into account when purchasing furniture and the materials preferred

\begin{tabular}{|c|c|c|c|c|c|}
\hline General characteristics & $\mathbf{F}$ & $\%$ & Material preferences & $\mathbf{F}$ & $\%$ \\
\hline Quality & 123 & 76.9 & Melamine coated fiberboard/MDF & 40 & 25 \\
\hline Aesthetics & 93 & 58.1 & Metal & 4 & 2.5 \\
\hline Not containing harmful substances & 76 & 47.5 & Polished wood plate & 32 & 20 \\
\hline Durability & 102 & 63.8 & Polished wood & 36 & 22.5 \\
\hline Functionality & 46 & 28.8 & PVC & 2 & 1.3 \\
\hline Safety/security & 99 & 61.9 & Lacquered paint over MDF & 66 & 41.3 \\
\hline Guarantee period & 56 & 35 & Others & 2 & 1.3 \\
\hline Others & 18 & 11.3 & - & - & - \\
\hline
\end{tabular}

potted plants in their rooms than the boys, and that as the age increases, so does the rate of presence of potted plants in rooms. Plants are important for children development but as seen above it is in very small portion of the participants' children bedroom which supports again $\mathrm{H} 3$.

\section{Findings on Children's Room Furniture}

It was found that in purchasing of the furniture in the rooms of the children of the families that participated in the study, $51.9 \%$ was purchased by the parents, $31.9 \%$ was bought jointly by the parents and the children, $8.1 \%$ was purchased by the child and in $8.8 \%$ other people were involved. According to this it can be seen that the parents decisions are dominant. The type and the presence percentage of different types of furniture is given in. The selected furniture types by the participants are very common and just only corresponding the necessary function, So, these findings are supporting $\mathrm{H} 2$ Table 8 below.

According to Table 8 in $60.6 \%$ of the children's rooms there is a bed with bed base with storage, $39.4 \%$ bedstead, $88.8 \%$ wardrobe, $69.4 \%$ study table, $54.4 \%$ chest of drawers, $48.1 \%$ bookshelves and in $31.9 \%$ bedside table. In conclusion it can be seen that specially in the rooms of children of school age, there are study tables and bookshelves and that use of a bed with bed base with storage is dominant. The characteristics taken into account when purchasing children's rooms furniture and the materials they prefer by the families that participated in the study is given in Table 9 below.

According to Table 9, of the families that are purchasing children's rooms furniture $(76.9 \%)$ place importance on quality, (63.8\%) for durability, (61.9\%) for safety and (58.1\%) for aesthetics. Also $41.3 \%$ of the purchased children's rooms furniture is lacquered MDF, $22.5 \%$ is polished wood, $20 \%$ polished wood plating and 5\% melamine coated chipboard/ MDF. These results indicate that the families place importance on quality, durability, safety and aesthetics, and on the other hand that they did not prefer materials like PVC and metal. Table 8 and 9 supports $\mathrm{H} 2, \mathrm{H} 5$ and partially $\mathrm{H} 3$. these issues mostly related with functionality, lack of children's' development and effected from contemporary market. Since these items are most commonly presented.When the families that participated in the study were purchasing children's rooms furniture the factors relating to safety that was important for them is given $\mathrm{H} 2, \mathrm{H} 3$ in Table 10 .

According to Table 10 it can be seen that majority of the families when purchasing furniture took into account the following factors in the percentages given; 
Table 10. Factors taken into account when purchasing children's rooms furniture

\begin{tabular}{|c|c|c|c|c|}
\hline \multirow[t]{2}{*}{ Factors taken into account in furniture } & \multicolumn{2}{|c|}{ Considered } & \multicolumn{2}{|c|}{ Not considered } \\
\hline & $\mathbf{F}$ & $\%$ & $\mathbf{F}$ & $\%$ \\
\hline Sharp corners & 124 & 77.5 & 36 & 22.5 \\
\hline Locks on covers and drawers & 39 & 24.4 & 121 & 75.6 \\
\hline No glass in furniture & 142 & 88.7 & 18 & 11.3 \\
\hline Wardrobe height not too high & 35 & 21.9 & 125 & 78.1 \\
\hline Ability to fix wardrobe on the wall & 55 & 34.4 & 105 & 65.6 \\
\hline
\end{tabular}

no glass used (\%88.7) and sharp corners (\%77.5). Also $34.4 \%$ of the families took into consideration ability to fix the wardrobe onto the wall, $24.4 \%$ (mainly families with toddlers) that the covers and the drawers were lockable and $21.9 \%$ that the wardrobe was not too high. From these results it can be deduced that the families placed importance on the lack of use of glass and sharp corners in furniture on children's rooms and another section was concerned that the wardrobe was not too high to prevent tipping over $(34.4 \%+21.9 \%)$. The results do not match with $\mathrm{H} 3$ while safety is also an important matter of children development.

\section{Conclusion and Discussion}

As stated by Demiraslan \& Aytore (2004); although the rights of the group of human beings in the $0-13$ age group labeled as children, they make up an important part of the world population. Although they have their rights protected by lots of legislation in developed and in developing countries, they are not sufficiently represented even in developed countries when taking environmental decisions. Therefore this privileged status that has been afforded to a child stops being "a right". The children under the supervision of adults that can decide which school they go to and what they wear and many other matters do not have any say in the decisions of the shaping and design of their bedrooms. As a result the children are required to accept the decisions of the adults in terms of shaping of their worlds. And adults who organize the children bedrooms' spaces presume that children will find this space amenable.

Along taking this important fact as the main concern of this study, it has been determined that in purchasing of the furniture for the children's bedrooms of the children of the families that participated in the study; $51.9 \%$ was purchased by the parents, $31.9 \%$ was bought jointly by the parents and the children, and $8.8 \%$ other people were involved and that only
$8.1 \%$ was directly selected by children. Results obtained in many other scientific studies on children's rooms spaces and internal fittings are confirmed with this study (Burdurlu et al., 2004). This study shows that the children have to live in joint spaces that had not been specifically designed for them, but for adults in the housing environments.

On the other hand, present day, due to increasing possibilities and relatively exploratory mass communication tools, parents are more and more aware about the great influence of the physical environment on the development of children. Working and stay at home mothers are placing more importance to the property of their children physical environments (Yalcin, 2011). However this point of view is another aspect of discussion. Below is a summary of the functional issues on the questionnaire for the developmental requirements of children:

According to the results that emerged from the study, 0-4 age group children had less rooms of their own in comparison to other age groups. Half of the children's rooms were $8-10 \mathrm{~m}^{2}$ big while the other half was between 11-13 $\mathrm{m}^{2}$. In the Chi-Square test carried out in this scope it was determined that there was no statistically significant difference (at the $p<0.05$ level) between children's rooms dimensions according to age or gender groups. This demonstrates that whatever the age of the child, however young the child, a separate room of their own and the dimensions of the room are factors that support the child's development in terms of providing independence, feeling of belonging and privacy in addition other benefits.

The interior spaces of the bedrooms carpets were used over wood laminate parquet floors. On 31.3\% of the floors, carpets were used over wood parquet floors. Form these and other results it can be seen that, on the floors of the rooms wood or wood based materials were used, and water based paint was used 
on the majority of the rooms and the girls rooms on the whole preferred pink and white paint while boys rooms had blue and white. Therefore it can be seen the parents generally prefer healthy, safe but similar interior space attributes.

It has further been demonstrated that the 8-10 age group children like to spend more time in their rooms in comparison to other age groups and also that girls like their room and spend more time in their rooms compared to boys of the same group.

On the other hand it was observed that there are study desks and book shelves in the rooms of school age children and that bed with bed base with storage is used on the whole in their bedrooms. It was also demonstrated that parents place importance on quality, durability, safety and aesthetic appearance in furniture and also that they do not like use of materials like PVC and metals in furniture. In addition it was also exhibited that the use of sharp corners and glass was not desirable while other parents were cautious about the tipping over high furniture $(34.4 \%+21.9 \%)$. Again all these aspects are about functionality and physical requirements therefore all these results also support the main premise and almost all hypothesis of the study.

In such a way that although parents are very influential in the formation of children's spaces, they still prefer functionality and conventional room designs in their decisions about the interior and furniture selections for their children's' room. However children's spaces house very many similar erroneous qualities, despite the fact that there is opportunity to use limitless design elements to be able to enrich children's imagination in interior design. As a consequence of taking advantage of the possibilities offered to children, they can develop their independence and creativity, and can experience many elements that can satisfy their psycho-social needs, at the same time. When spatial experience and stimulation is evaluated, then this would be dependent on the physical and semantic properties possessed by the space. Therefore the physical environments that develop the children's personalities, preferences, their knowledge and skills must consist of original designs.

The conclusion to be drawn from all these findings is that in addition to functional requirements of the children's spaces, the space designs carried out with the consideration of the physical and mental development of children must be for support of the child's imagination and they must ensure that the child likes its housing living environment. In order to achieve this, when designing children's rooms, the design must be presented so as to combine learning and play activities, and to encapsulate many alternatives in design. A child's room must contain many elements of spatial design features in order to fulfill some necessities such as, care of the child, feeding, love and affection, movement, adult support, ability to be other children, self-recognition, to prove themselves, supportive of independence and creativity and ability to develop creativity.

\section{Acknowledgements}

The authors would like to thank Aslıgül Chin for her careful proofreading of the English text and to Ömer Sarıerikli and Süleyman Baltaci who contributed to the acquisition of research data.

\section{References}

Bozdayı, A.M. (1988) Children in The Physical Environment An Approach To Design For Children A Day Care Centre Proposal In Beytepe. Ankara: Theses of MS, Faculty of Architecture, METU.

Burdurlu, E., Kılıç, Y., İlçe, A.C., Elibol, G.C., Yener, G. (2004) "Parents expectations of Preschool child furniture and their projected design criteria", Journal of Technology, Volume 7, pp.139-149.

Büyükpamukçu, H. (2004) Design Considerations in children Bedroom Furniture of Preschool Period with an Analysis of Today's Turkish Children Furniture Market. Ankara: Theses of MS, Industrial Design Faculty, METU.

Christensen, P., James, A. (2000) "Research with Children: Perspectives and Practices". London: Falmer Press.

Day, C., Midbjer, A. (2007) Environment and children: Passive lessons from the everyday environment ( $1^{\text {st }}$ ed.). Amsterdam, NL and London, UK: Architectural Press.

Demirarslan, D., Aytöre, S. (2004) Importance of the Furniture Design on 0-6 aged children in terms of Cognitive Development, 4.th International Design and Sentimental Experience Conference, 12-14 $4^{\text {th }}$ July 2004, ODTÜ.

Doğramacı, F. (1994) An Approach on 3-6 aged Childs' Bedroom and Design CriteriaHacettepe University, Institute of Social Science, Theses of MS.

Dudek, M. (2000) Kindergarten Architecture: Space for the Imagination. Second edition. London, UK: Spon Press.

Dudek, M. (2001) Building for Young Children: A Practical Guide to Planning, Designing and Building thePerfect Space. London, UK: National Early Years Network.

Dudek, M. (ed.). (2005) Children's Spaces. London, UK: Architectural Press.

Egill, L. (2002) “Child' Room”. Paris: Le Cherche-Midi.

Feldman, R. S. (2007) Child Development (4 ${ }^{\text {th }}$ ed.). Upper Saddle River, NJ: Pearson Prentice Hall

Frost, J.L., Wortham, S., Reifel, S. (2001) "Play and Child Development. New Jersey: Prentice-Hall.

Garbarini, H.A. (1999) "Kids' Bedrooms." Good Housekeeping 229 pp. 56-58. 
Gifford, R., Lacombe C. (2006) “Children spend more time in their homes than anywhere else" Journal of Housing Built Environment 21:177-189.

Gür, Ö.Ş., Zorlu, T. (2002) Children Spaces. İstanbul: YemYayınları.

Işık, Z. (1992) Analysis of Traditional and Contemporary Residential Interiors, Gazi University, Institute of Science and Technology, PhD Thesis, pp 1-10.

Kanbay, H. (1993) "Children Rooms", Art Dekor AD, 3/6, s.46-62.

Korpela, K., Kytt, M., Hartig, T. (2002) "Restorative Experience, Self-Regulations, and Children's Place Preferences" Journal of Environmental Psychology 22, pp 387-398.

Li, L., H. (2011) "Impact of housing design factors on children's conduct at school: an empirical study of Hong Kong" Hous. and the Built Environ. 26:427-439.

Miller, S. (1986) "Designing the Home for Children; A need based Approach" Vol. 3 No.1 (Spring) Children's Environments Quarterly, pp. 55-70.

Moore, G.T. (2002) Designed environments for young children: Empirical findings and implications for planning and design. In M. Gallop \& J. McCormack (Eds.), Children and Young People's Environments (pp. 53-63). Dunedin, New Zealand: University of Otago, Children's Issues Centre.

Read, M.A. (2007) Sense of Place in Child Care Environments. Early Childhood Education Journal, pp 387-392.

Rudge, C., Driskoll, V. (2005) Channels for listening to young children and to parents. In: Clark, A.,

Şener, E.A. (2001) "A reversible/ transformable/ flexible "Physical Environment Model" for Preschool Education Centers". İstanbul: Theses of PhD, İstanbul Technical University, Natural Science Institute.

Stankovic, D., Milojkovic A., Tanic, M. (2006) Physical Environment Factors and Their Impact on the Cognitive Process and Social Behavior of Children in the Preschool Facilities. FactaUniversitesi: Architecture and Civil Engineering, pp. 51-57.

Stankovic, D., Stojic, J. (2007) Psycho-Developing Needs of
Children and Spatial Features for Children's Stay. FactaUniversitesi: Architecture and Civil Engineering, pp. 71-75.

Tolfree, D., Woodhead, M. (1999) Tapping a key resource. Early Childhood Matters 91: pp.19-23.

Veechi, V. (1998) What kind of space for living well in school? In: Ceppi, G. and Zini, M. Children's Spaces And Relations: Metaproject For The Environment of Young Children. Domus Academy ResearchCenter: Reggio Children.

Weinstein, C., David, T. (1987) Spaces for Children: The Built Environment and Child Development. New York, USA and London, UK: Plenum Press.

Yalcin, M. (2011) Affects of the Physical Environment in the Preschool Education Spaces over Child Development and Psycho-Social Determinants Effecting Their Spatial Formation. Ph.D. Dissertation, Institute of Social Sciences, Hacettepe University, Ankara.

Yavuzer, H. (2008) Children Psychology, RemziKitabevi: İstanbul.

Yildirim, K. (1995) Optimum Solutions For The Parents' Bedroom Planning in the Moderate (SES) Houses, User Requirements Related to Activities and the Interior Equipment Elements, Gazi University, Institute of Science and Technology, M.Sc. Thesis, pp 145-149.

Yildirim, K., Hacibaloglu, M. (2000) An Ergonomic Investigation on House Kitchens, G.U. Journal of Science, Vol.13, No:3, 549-566.

Yildirim, K., Hidayetoglu, M., Baskaya, A. (2005) Satisfaction with the Fixed Interior Furniture of Block-Houses of Different Socio-Economic Status, Journal of Politeknik, Vol. 8 , No 2 .

Yildirim, K., Baskaya, A. (2006) Evaluation of Main Living Room in Block Housing By Users of Different Revenue Groups, Journal of Fac. Eng. Arch. Gazi Univ., Vol 20, No 4, 473-481.

Yildirim, K., Hidayetoglu, M.L. (2008) Effects of the locations of curved areas in the main living rooms of apartment housing on user perceptions, G.U. Journal of Science, Vol. 21 (2): 1-12. 